\title{
The Efficacy of Budgeting as a Control Measure in Developing Economies: A Study from Nigeria
}

\author{
Segun Abogun \\ Department of Accounting and Finance, University of Ilorin, Nigeria \\ Tel: 234-803-915-6876Ｅ-mail: segunstc@yahoo.com \\ Temitope Olamide Fagbemi \\ Department of Accounting and Finance, University of Ilorin, Nigeria \\ Tel: 234-802-038-2535 E-mail: olamidefag@yahoo.com
}

$\begin{array}{lr}\text { Received: July 14, } 2011 & \text { Accepted: November 22, } 2011 \quad \text { Published: January 1, } 2012 \\ \text { doi:10.5539/ass.v8n1p176 } & \text { URL: http://dx.doi.org/10.5539/ass.v8n1p176 }\end{array}$

\begin{abstract}
The effectiveness of budgeting has a link with the level of environmental volatility. It means that, how effective budgeting would be in controlling the activities of any organisation depends largely on the environmental volatility under which such budget is operated. Empirical evidence on the effect of environmental factors on budgeting and budget effectiveness in Nigeria, an emerging economy has been scanty. This gap in the literature is the focus of this study. The primary source of data was used and data were collected through the use of questionnaire. Hypotheses were formulated and tested using inferential statistics. Findings did not provide strong evidence on the effectiveness of budgeting as a control measure. This is not consistent with evidences from the developed world. The findings also reveal those factors affecting the effectiveness of budgeting in Nigeria.
\end{abstract}

Keywords: Budgeting, Budget control, Budget effectiveness, Developing economies, Environmental factors

\section{Introduction}

Nigeria is a country endowed with all kinds of resources; human, material, capital and otherwise. However, in spite of her huge potentials, the country is still either believed to be a third world country or a developing one. This may be as a result of the level of corruption, bad economy, low production, high importation of good and services, inadequate infrastructural facilities; to mention but a few. All these have consequences for business. Inconsistency in government policy is another major issue characterising the business environment in Nigeria. No doubt, the above mentioned factors contribute largely to the high cost of doing business in Nigeria. Therefore, it may be said that for businesses to thrive well in the Nigerian environment, these problems would have to be surmounted.

According to Pilkington \& Crowther (2007) and Kren (1992), the effectiveness of budgeting has a link with the level of environmental volatility. It means that, how effective budgeting would be in controlling the activities of any organisation depends largely on the environmental volatility under which such budget is operated. In other word, in a conducive business environment, the role of budgeting cannot be over emphasized. For instance, Horngren et al., (2008) mentioned that the effectiveness of budgeting for planning, motivating, communicating and controlling in the developed world is evident.

Now, the questions raised in this study are

1) Is there any relationship between the actual operation of industries and the budget prepared?

2) Are environmental factors affecting the success of budgeting in Nigeria?

The answer to the above questions is the drive for this study. The general objective of this study therefore is to ascertain whether or not budgeting is an effective tool for control in the Nigerian manufacturing industry.

The study hypothesised that:

1) There is no positive connection between budget and actual performance. 
2) Certain environmental factors (e.g. inconsistency in government policy, poor infrastructures, corruption) do not affect the effectiveness of budgeting in Nigeria.

One limitation to past researches on this area is that, many of the empirical studies on budgeting and control focused their investigation on manufacturing companies in the developed countries such as US, Europe and Australia (Jermias \& Setiawan, 2007). Few studies, if any have looked at the effectiveness of budgetary process in helping management control action to achieve the set objectives in the developing countries, especially Nigeria. This study addresses this gap. Furthermore, this study provides empirical evidence on budgeting as a management control with the private sector (manufacturing) in focus against most researches on this area conducted on the public sector.

The remaining part of this study is divided into three sections. The next reviews literatures. The third section describes the research methods while the fourth section was used to analyse data and present the results. Section five concludes the paper.

\section{Review of Related Literature}

\subsection{Conceptual Framework}

Horngren et al. (2008), define budget as a quantitative expression of a plan of action. Atkinson et al. (1997), also define budget as a quantitative expression of the money inflows and outflows to determine whether a financial plan will meet organization goal. The definitions above do not mention the object of time to which a budget relates. A budget should always be in respect of a period of time, it could be half yearly, yearly, quarterly, monthly, weekly, daily, or other time periods (Harper, 1995; Frederick, 2001). A budget is also not just a quantitative expression of a plan of action but a quantitative economic plan. For a plan of action to be referred to as a budget it must be in economic term (Harper, 1995). The literature also posits that a budget is a quantitative expression of a plan of action prepared in advance of the budget period (Lucey, 2000). Lucey identifies that budgets may be prepared for the business as a whole, for departments or functions with a link with the over all objectives of an organization. The valuable use of budgets for translating organizational objectives to feasible plan of action is a major breakthrough against the ordinary use of budgets for cutting cost, restricting spending and allocating scarce resources.

In extant literatures, most people associate the word budget primarily with limitation on spending (Horngren et al., 2008; Theiss, 1935; Burkhead, 1947). For example, government often approves a spending budget and then maintains expenditure within the limit prescribed by the budgets (Ehrhart et al., 2006). In other word, budget was viewed as just a statement that shows the estimate of expenditure and possible revenue for future period. It is believed that as soon as budget proposals are approved or signed into law, a contract exists and nothing more. It becomes an authorization for spending and raising revenue. The justification for this perception of budget may be entrenched in the history of budgeting (For history, see, Wickramasinghe \& Alawattage, 2007). In some other literatures, budgets are usually perceived as statements having no link with the strategic and operational objectives of organisations. Amalokwu \& Lawrence (2008) for example, emphasise that in too many cases, budgets for allocation and spending money have little connection with business or operational strategies (see for details, Brumby and Robin, 2005). This in essence, may limit the usefulness of budgeting to restriction on expenditure only (see also, Holloway \& Rueck, 2002). More so, the role of performance measurements in budgeting cannot be ignored as its exclusion may greatly reduce its control potentials (see, Grifel, 1993; Millians, 1947; Robinson \& Brumby, 2005). On the other hand, some literatures reveal that budgets are strategically focused and that performance measures in it are used in benchmarking (Anand et al., 2005; Dunbar, 1971; Jacobs, 2004). For the purpose of this study however, budgeting is perceived to be linked with organisational objectives. That is, the usefulness of budgeting goes beyond restriction on spending.

Furthermore, other writers reveal that through budgeting, management can perform its numerous tasks (Grifel, 1993; Schwartz, 2008; Millar, 1997; Yeung et al., 2006; Lucey, 2000; Otley, 1978). Some of the principal roles of budgeting in management are for planning, control, coordinating, evaluating, directing, performance improvement, communication and decision making (Grifel, 1993; Zahirul \& Peter, 2007). In this study, the role of budgeting for planning and control are in focus.

\subsection{Theoretical Framework}

\subsubsection{Control}

Horngren et al. (2008), view management control system as "a logical integration of technique for gathering and using information to make planning and control decisions, for motivating employee behavior, and for evaluating performance." (see for example, Omolehinwa, 2000, 2005; Glautier \& Underdown, 2001; Atkinson et al., 1997). It 
is however important to note that, for the purpose of this study the definitions that perceive control as a feedback mechanism, that monitors, evaluates and compares actual results with standards for corrective action so as to achieve set objectives are considered. This is because the purpose of this study is to find out the effectiveness of budgetary process in helping management achieve set objectives.

\subsubsection{Management Control through Budgeting}

Using a control model (organizational control) in figure.1.1, management control through budgeting is explained. In figure 1.1, it is evident that budgeting is the core of both planning and control function of management.

Furthermore, Meign \& Meigs (1981), explain that another use of budget for control purpose is in evaluating performance. They argue that organizational plans are carried out by people, thus, control is exercise not over operations, revenue, costs, but over the persons responsible for those operations and the related revenue and expenses (see for example, Otley, 1978). Relying on financial measures alone is insufficient to ensure that strategy will be executed successfully. The solution to this is to measure and evaluate business unit managers using multiple measures, non financial as well as financial (Anthony \& Govindarajan, 2004 cited in Amalokwu \& Lawrence, 2008).

More so, it is important to note that, business environment are ever changing and highly competitive, therefore fixed budget is not desirable. Instead, flexible budgeting technique and forecasting should be adopted (see for details CIMA-ICAEW 2004; Horngren et al., 2008; Wickramasinghe \& Alawattage 2007). From fig. 1.1, it is also important to note that, at the control phase, strategic, operational objectives and budgetary planning can be revised if necessary. This is to reflect the changes in the environment (Hansen et al., 2003; Frederick 2001). In other word, control system can be feedback or feed forward system; the former is based on past data and the latter on planned data (Wickramasinghe \& Alawattage, 2007).

More importantly, for budgets to serve as effective control tools, the following prerequisites are essential: organizational goals and objectives; well defined organizational structure; sound accounting information system; well defined responsibility centres; proper cost classification and coding; performance measures; prompt access to external information; efficient information technology method (see for detail, Jermias \& Setiawan, 2008; Dunbar, 1971; Theiss, 1935; Thompson \& Gate, 2007; Jacob, 2004; Callahan \& Waymire, 2007; Druker, 1931; Pollack \& Zeckhauser, 1996; Zahirul \& Peter, 2007; Grifel, 1993; Kren, 1992; Hansen et al., 2003; Anand et al., 2005).

\section{Research Methodology}

The target population for this study consists of all the manufacturing companies in the Nigerian private sector. For the purpose of this study, the list of manufacturing companies in Lagos State of Nigeria constitutes the population of study. The choice of Lagos state was based on certain reports on the distribution of manufacturing companies in Nigeria. According to Ajibolade (2008), over 55\% of manufacturing companies had their head offices located in Lagos. Therefore, it is believed that the choice of Lagos is appropriate for this study. The choice of manufacturing sector for this study was based on the belief that budgeting is most widely practiced in the manufacturing sector compared to other sectors. Moreso, Wickramasinghe \& Alawattage (2007), posit that the development of standard costing technique and budgeting is traceable to the manufacturing industries.

Convenience sampling technique was used. The adoption of this sampling method was based on the fact that the study did not use any sampling frame from which a random sample could be drawn. However, for the fact that budgeting is widely used by most manufacturing companies, there is no reason to suspect any systematic bias in the findings of this study.

The instrument used for data collection was the questionnaire. The questionnaire was developed in line with instruments in previous study. (see for example, Mahoney et al., 1965; Vroom \& Mann, 1960; Ouchi \& Maguire, 1975; Milani, 1975 -all cited in Jermias \& Setiawan, 2008). A five point Likert scale was used in designing the questionnaire where respondents were asked to rate their opinion from two extremes, "Strongly disagree and strongly agree". This was to give the respondents the latitude or wide ranging options from which to choose the one that best reflects their opinion. The nature of the data needed requires respondents to have the requisite knowledge and experience about the subject matter. Therefore, the target respondents for this study were: the staff in the account section; departmental heads; and management staff in each of the sampled companies. One hundred and fifty one (151) questionnaires were administered across the companies sampled but only one hundred and ten (110) were retrieved constituting about $73 \%$ response rate.

Three variables were identified and examined. These are: budget; actual performance; factors affecting budget effectiveness. In order to measure budget, the instrument asked the respondents to indicate on a 5-point Likert scale ranging from one to five, the extent to which their companies operate formal budgets and control actions. 
Budgeting and budgetary control were merged together to represent the independent variable (Budget). In order to measure actual performance, the instrument asked respondents to indicate the extent to which actual performance conformed to the budgets. This represents the dependent variable. Caiden (1980) highlights some factors responsible for budget failure in developing countries. E.g. policy inconsistency of government, hyper inflation, poor data base, and poor IT, Poor infrastructures resulting to high cost of doing business, poor commitment to budget implementation, and corruption. The instrument therefore asked respondents to indicate the extent to which they agree or disagree that those factors affect the effectiveness of budgeting in Nigeria.

In this study, inferential statistical procedures were used. The inferential statistics used were the Spearman's Rank Correlation and the Chi-Square test. The Spearman's Rank Correlation was considered appropriate because the required data were not available in numerical form for doing correlation analysis but the information was sufficient to rank the data as first, second, third and so forth (see Kothari, 2004 and Bluman, 2004). The Chi-Square was used to test the extent to which the observed frequency differs from the expected.

\section{Results}

\subsection{Correlation Analysis}

Basically, the variables used for the correlation exercise were budget and actual result/performance. Budget was operationalised by summing up the reactions of respondents to certain items in the questionnaire on budgeting and budgetary control. The second variable (Actual results) was operationalised by summing up the reactions of respondents to certain items in the questionnaire on management control system in their companies. The two variables were correlated to identify if there existed a relationship between them. Table 1 shows that there is a positive but weak correlation between budget and actual performance as explained by the spearman's rho, $\mathrm{r}_{\mathrm{s}}=$ 0.460 .

\subsection{Hypotheses Testing}

In this study, hypotheses were tested. In other to test for the effectiveness of budgeting as a control measure in Nigeria, the hypothesis of no connection between budget and actual results was formulated. The hypothesis was stated as:

$\mathrm{Ho}_{1}$ : There is no positive connection between budget and actual performance.

Table 1 reveals that $r_{s}=0.460$ with a p-value less than 0.05 , therefore the null hypothesis was rejected. As a result, the alternative hypothesis was accepted. It means therefore that, there is a connection between budget and actual performance though the connection is weak.

This study also hypothesised that

$\mathrm{Ho}_{2}$ : Certain factors (economic, political, and social) do not affect the effectiveness of budgeting.

From Table 2, the $\chi^{2}$ value is equal to 121.229 at a degree of freedom of 4 and $p<0.05$. Thus, this hypothesis is significant. As a result, the null hypothesis was rejected thereby accepting the alternative.

\subsection{Interpretation of Results}

Given that the result of the Spearman's Rank Correlation Coefficient is 0.460 , the null hypothesis of no connection was not accepted. The result also shows that certain factors affect budgeting in Nigeria. The interpretation of $r_{s}$ 0.460 is that there is a positive but weak connection between actual performance and budget. It means that the more the companies tighten their budgets and budgetary control, the closer the actual performance to the set targets. The non-acceptance of the null hypothesis further shows that there is connection between actual performance and budgets. By this, the study reveals that budgeting is an effective tool for management control. Albeit, the effectiveness is not strong. From this study, it is believed that the weak positive connection between budgets and actual performance could be explained by the effect of certain factors that the test of the second hypothesis reveals.

However it is important to note that the findings of this study on the effectiveness of budgeting for control is on one hand, consistent with the findings of Callahan and Waymire (2007), who stated that their study informs the debate about the appropriate use of budgeting by offering evidence that the effective level of budgeting control is positively associated with performance. On the other hand, the findings show that the connection between budgets and actual performance is a weak one which indicates weak budget effectiveness. This is not consistent with the evidence from the developed countries that budget is strongly associated performance (Callahan \& Waymire, 2007). Furthermore, Horngren et al., (2008) stated that, in a survey carried out in the North America, budget was rated the highest cost management tool for cost reduction and control. This study therefore contributes to the existing literature on budgeting that in the developing nations, budgeting is effective for control but not as it were in the developed countries due to some environmental challenges. 


\section{Summary, Conclusion and Recommendation}

The study reveals that there is no strong evidence that budgeting is an effective tool for control in a developing economy as against the strong evidence from the developed countries. This can be as a result of the following factors as the study reveals. These factors are: policy inconsistency of government, inflation, poor database if there is any, poor infrastructural facilities, and corruption.

Therefore, it is recommended that budget should be reviewed on a regular basis to reflect the ever changing and highly competitive business environment. It is also recommended that efforts should be channelled by the government to remove those problems inhibiting the effectiveness of budgeting so that companies can thrive, and improve performances.

\section{References}

Ajibolade, S. O. (2008). The impact of improved management accounting systems on manufacturing sector performance in Nigeria, Unpublished Doctoral Thesis, University of Lagos, Nigeria.

Amalokwu, O. \& Lawrence, N. N. (2008). Budgetary and management control process in a manufacturing organization. Unpublished Master of Science Dissertation, Malardalen University, Malardalen.

Anand, M., Sahay, B. S. \& Saha, S. (2005). Cost Management Practices in India: An Empirical Study. ASC1 Journal of Management, 33(1\&2), 1-15. [Online] Available: http://journal.asci.org.in/Vol.33(2004)/01.\%20Anand,\%20Sahay\%20\&\%20Saha.pdf (December 5, 2008)

Atkinson, A. A., Banker, R.D., Kaplan, R.S. \& Markyoung, S. (1997). Management Accounting, ( $2^{\text {nd }}$ Ed.) New Jersey: Prentice Hall Inc.

Bluman, G. A. (2004). Elementary Statistics: A Step by Step Approach. New York: McGraw Hill.

Brumby, J. \& Robinson, M. (2005). Does Performance Budgeting Works? An Analytical Review of the Empirical Literature. IMF working paper (wp/05/210). [Online] Available: http://cdi.mecon.gov.ar/docelec/fmi/wp/wp05210.pdf_April 12, 2009)

Burkhead, V. S. (1947). Budget Classification and Fiscal Planning. Public Administration Review, 7(4), 228-235. http://dx.doi.org/10.2307/972407

Caiden, N. (1980). Budgeting in Poor Countries: Ten Assumptions Re-examined. Public Administration Review, 40(1), 40-46. http://dx.doi.org/10.2307/976107

Callahan, C. M. \& Waymire, T. R. (2007). An Examination of the Effect of Budgetary Control on Performance: Evidence from Cities. [Online] Available: http://papers.ssrn.com/sol3/papers.cfm?abstract_id=1003930 (February 12, 2009)

CIMA-ICAEW. (2004). A Report on Better Budgeting Forum. [Online] Available: http:// www.icaew.com./index.cfm/route (December 16, 2008), July.

Drucker, A. P. R. (1931). Budgeting and Control Machinery. American Accounting Information, 6(3), 192-196.

Dunbar, R. L. M. (1971). Budgeting for Control. Administrative Science, 16(1), 88-96.

Ehrhart, K., Jurgenvon, H., Roy, G. \& Claudia, K. (2006). Budget Process: Theory and Experimental Evidence. CAEPR Working Paper No. 2006-009. [Online] Available: http://papers.ssrn.com/sol3/papers.cfm?abstract_id=932692 (November 11, 2008)

Frederick, D. (2001). Budgetary Monitoring and Control. [Online] Available: www.BNET.htm (November 13, 2008)

Glautier, M. W. E. \& Underdown, B. (2001). Accounting Theory and Practice. England: Pearson Educational Limited.

Grifel, S. S. (1993). Performance Measurement and Budgetary Decision Making. Public Productive and Management Review, 16(4), 403-407. http://dx.doi.org/10.2307/3381018

Hansen, S. C., Otley, T. D. \& Van der Stede, W. A. (2003). Practice Developments in Budgeting: An Overview and Research Perspective. Journal of Management Accounting Research, 15, 95-116. http://dx.doi.org/10.2308/jmar.2003.15.1.95

Harper, W. M. (1995). Cost and Management Accounting. England: Prentice Hall, Pearson Education. 
Holloway, D. A. \& DeReuck, J. D. (2002). Beyond a Traditional Budgeting Orientation: Towards a Commitment to General Decision Assurance. Asia Pacific Interdisciplinary Research in Accounting Conference, July, Adelaide, pp. 1- 21.

Horngren, C. T., Sundem, G. L., Stratton, W. O., Burgstahler, D. \& Schatzberg, J. (2008). Introduction to Management Accounting, (14 ${ }^{\text {th }}$ Ed.) New Jersey: Pearson Prentice Hall.

Jacobs, J. F. (2004). Budgeting and Budgetary Control. [Online] Available: http://www.ssrn.com (November 24, 2008)

Jermias, J. \& Setiawan, T. (2008). The Moderating Effects of Hierarchy and Control on the Relationship between Budgetary Participation and Performance. The International Journal of Accounting, 43, 268-292. http://dx.doi.org/10.1016/j.intacc.2008.06.009

Kothari, C. R. (2004). Research Methodology Methods and Techniques. Delhi: New Age International Publishing. Kren, L. (1992). Budgetary Participation and Managerial Performance: The Impact of Information and Environmental Volatility. The Accounting Review, 67(3), 511-526.

Lucey, T. (2000). Costing. London: Letts Educational.

Meign, W. B. \& Meigs, F. R. (1981). The Basis for Business Decisions, $5^{\text {th }}$ Ed. New York: McGraw-Hill.

Millar, J. (1997). The Effects of Budgets Rules on Fiscal Performance and Macroeconomic Stabilization. [Online] Available: http://www.bank-banque-canada.ca (December 4, 2008)

Millians, M. P. (1947). Profit Planning and Budgetary Control. The Accounting Review, 22(1), 65-68.

Omolehinwa, E. (2000). Coping with Cost Accounting. Lagos: Pumark Nigeria Limited.

Omolehinwa, E. (2005). Government Budgeting and Accounting in Nigeria. Lagos: Pumark Nigeria Limited.

Otley, D.T. (1978). Budgets Use and Managerial Performance. Journal of Accounting Research, 16(1), 122-149. http://dx.doi.org/10.2307/2490414

Pilkington, M. \& Crowther, D. (2007). Budgeting and Control. Financial Management. [Online] Available: www.cimaglobal.com/financialmanagement (December 18, 2008)

Polimeni, R. S., Fabozzi, F.J. \& Adelberg, A.H. (1991). Cost Accounting: Concept and Application for Managerial Decision Making, ( $3^{\text {rd }}$ Ed.) New York: McGraw-Hill, Inc.

Pollack, H. \& Zeckhauser, R. (1996). Budgets as Dynamic Gatekeepers. Management Science, 42(5), 642-658. [Online] Available: http://www.jstor.org/stable/2634457 (November 21, 2008)

Schwartz, S. T., Nikias, A. D. \& Young, R. A. (2008). A Note on Bundling Budgets to Achieve Management Control. Journal of Accounting Education, 27(3): 168-184. http://dx.doi.org/10.1016/j.jaccedu.2010.06.003

Theiss, L. E. (1935). Accounting and Budgeting. The Accounting Review, 10(2), 156-161.

Thompson, E. \& Gates, B. L. (2007). Betting on the Future with a Cloudy Crystal Ball? Revenue Forecasting, Financial theory and Budget: An Expanded Treatment. Public Administration Review, 67(5), 48-66. http://dx.doi.org/10.1111/j.1540-6210.2007.00771_2.x

Wickramasinghe, D. \& Alawatage, C. (2007). Management Accounting Change: Approaches and Perspectives. New York: Routledge Taylor and Francis group.

Yeung, B. Y. (2006). Multinationals do it better: Evidence on the Efficiency of Corporations Capital Budgeting. [Online] Available: http://papers.ssrn.com/so13/cf_dev (November 27, 2008)

Zahirul, H. \& Peter, B. (2007). Aligning Industrials Relation Risk, Budgetary Participation, and Budgeting Measures of Performance: Impact on Managerial Performance. [Online] Available: http://papers.ssrn.com/so13/papers.cfm (December 1, 2008) 
Table 1. Correlations (Budget \& Actual Performance)

\begin{tabular}{|c|c|c|c|c|}
\hline \multirow{2}{*}{ Spearman's rho } & & & Budget & AP \\
\hline & Budget & $\begin{array}{l}\text { Correlation Coefficient } \\
\text { Sig. (2-tailed) } \\
\text { N }\end{array}$ & $\begin{array}{l}1.000 \\
110\end{array}$ & $\begin{array}{l}.460^{* *} \\
.000 \\
110\end{array}$ \\
\hline & $\begin{array}{l}\text { Actual } \\
\text { Performance } \\
\text { (AP) }\end{array}$ & $\begin{array}{l}\text { Correlation Coefficient } \\
\text { Sig. (2-tailed) } \\
\text { N }\end{array}$ & $\begin{array}{l}.460^{* *} \\
.000 \\
110\end{array}$ & $\begin{array}{l}1.000 \\
\cdot \\
110\end{array}$ \\
\hline
\end{tabular}

*. Correlation is significant at the 0.01 level (2-tailed).

Source: Field Survey

Table 2. Chi-Square Result

\begin{tabular}{|l|r|}
\hline & Environmental Factor* \\
\hline Chi-Square & 121.229 \\
df & 4 \\
Asymp. Sig & .000 \\
\hline
\end{tabular}

*Environmental factors identified are economic, political and social

Source: Field Survey

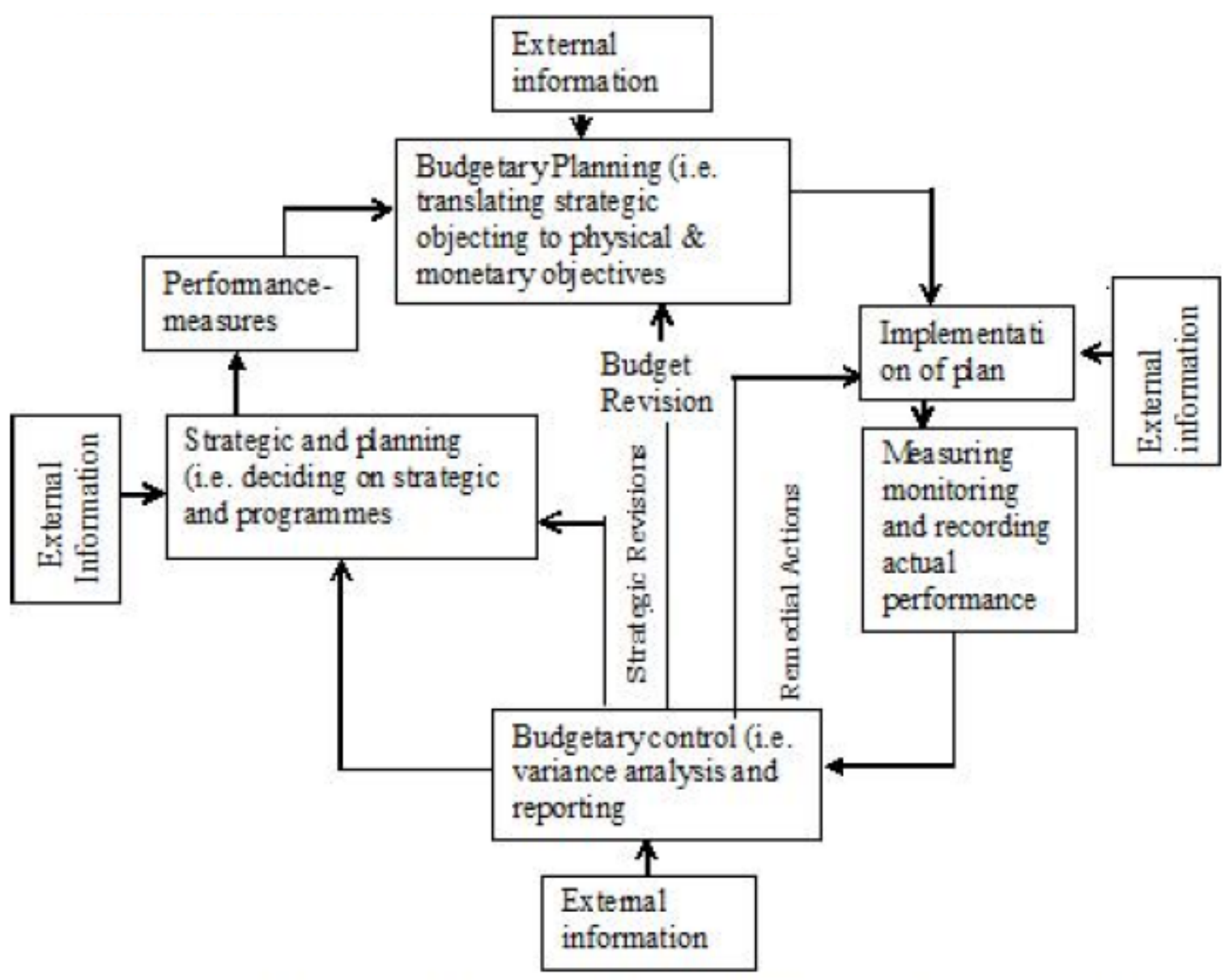

Figure 1. Management control process and budgeting

Source: Adapted from Anthony \& Dearden 1980, cited Wickramasinghe \& Alawatage, (2007), modified. 